\title{
E1784K Mutation in SCN5A and Overlap Syndrome
}

\author{
Naokata Sumitomo, MD, $\mathrm{PhD}$
}

$\mathbf{C}$ ongenital long QT syndrome (LQTS) is characterized by prolongation of the QT interval on the surface ECG and may cause syncope and seizures; there is a certain risk of fatal ventricular arrhythmias, torsade de pointes or ventricular fibrillation. ${ }^{1}$ The QT interval is determined by the cardiac action potential duration and is related to the many ion channels in the myocardial cells. The most important state of the ion currents for prolonging the QT interval is a decrease in the outward $\mathrm{K}$ current, and increase of the inward $\mathrm{Na}$ or $\mathrm{Ca}$ current. SCN5A is the gene encoding the most prevalent cardiac Na channel $\alpha$ subunit, and an SCN5A mutation is responsible for many hereditary arrhythmias including type 3 LQTS (LQT3), ${ }^{2}$ Brugada syndrome (BrS), ${ }^{3}$ progressive cardiac conduction disturbances (PCCD), ${ }^{4}$ sick sinus syndrome (SSS), 5,6 atrial fibrillation, ${ }^{6,7}$ atrial standstill, and sudden infant death syndrome (SIDS). ${ }^{8-10}$

\section{Article p 1974}

The most common SCN5A mutation in LQT3 causes a persistent $\mathrm{Na}$ current during the action potential plateau because of malfunctioning of the fast $\mathrm{Na}$ channel inactivation, ${ }^{2}$ and this delayed inactivation delays the repolarization of the myocardial cells, and leads to prolongation of the QT interval (Table).

In contrast, a reduction in the initial opening of the Na channels in the right ventricular epicardial cells may cause ST elevation in the right precordial leads and lead to BrS (Table).

Some PCCD patients develop this phenotype with aging, because the increased chance of fibrosis in association with genetic defects may impair propagation of the impulse through the conduction system. In some PCCD patients, a conduction defect is documented from birth. Depending on the consequence of the mutation on the sodium channels, the phenotype may be progressive or congenital (Table). ${ }^{4}$

If the action potential generation and/or propagation is more severely impaired in the atria than in the ventricles in SCN5A mutation patients, the sinus node dysfunction caused by failure of the impulses to conduct into the adjacent atrial myocardium (exit block) has been suggested as a cause of SSS, atrial standstill, and atrial fibrillation (Table). ${ }^{5}$

Mutations of E1784K in SCN5A cause a persistent (late) inward $\mathrm{Na}^{+}$current, and also cause a reduction in the peak $\mathrm{Na}^{+}$ current.9,11,12 Some LQT3 patients present with ECG findings characteristic of $\mathrm{BrS}$ (overlap syndrome), and one of the causes of this overlapping syndrome can be explained by E1784K, $, 11,12$ 1795insD, ${ }^{13,14} \Delta \mathrm{KPQ},{ }^{12,15}$ and $\Delta \mathrm{K} 1500 .{ }^{16}$ However, several other biophysical mechanisms may be related to the reduction in the peak Na current. ${ }^{17}$

Sodium-channel blockers are commonly used in patients with LQT3 because of the blocking effect on persistent $\mathrm{Na}$ currents. ${ }^{18-20}$ However, in overlap syndrome, sodium-channel blockers shorten the QT interval, possibly reducing the peak $\mathrm{Na}$ current, and thus uncover a concealed $\mathrm{BrS}$ resulting in typical ST segment elevation in the right precordial leads, and may provoke malignant ventricular arrhythmias. ${ }^{14}$

In this issue of the Journal, Takahashi et al report that the E1784K mutation in SCN5A is the most prevalent mutation in school children with LQTS in the Okinawa islands. ${ }^{21}$ The most common mutation in LQTS is reported to be a $K C N Q 1$ mutation. ${ }^{22,23}$ It is noteworthy that there is a high prevalence rate of

\begin{tabular}{|c|c|c|}
\hline Syndrome & Phenotype & Possible cause of the syndrome \\
\hline LQT3 & Prolonged QT & Persistent Na current \\
\hline $\mathrm{BrS}$ & $\begin{array}{l}\text { RBBB type QRS, ST elevation in the right } \\
\text { precordial leads }\end{array}$ & $\begin{array}{l}\text { Reduction in the initial opening of the } \mathrm{Na} \text { channels in the epicardial } \\
\text { right ventricular outflow tract cells }\end{array}$ \\
\hline PCCD & $\mathrm{BBB}, \mathrm{AVB}$ & Fibrosis and conduction disturbance of the conduction system \\
\hline SSS & Sinus bradycardia, SA block & $\begin{array}{l}\text { Failure of conduction from the sinus node (exit block), morphological } \\
\text { changes in the atrial cells }\end{array}$ \\
\hline Atrial standstill & Junctional rhythm without $P$ waves & Failure of conduction in the atrium \\
\hline AF & AF & Morphological changes of the atrial cells \\
\hline Overlap syndrome & LQT3, BrS, SSS & Persistent $\mathrm{Na}$ current and reduction in the initial $\mathrm{Na}$ current \\
\hline
\end{tabular}

AF, atrial fibrillation; AVB, AV block; BBB, bundle branch block; BrS, Brugada syndrome; LQT3, long QT type 3; PCCD, progressive cardiac conduction system disturbance; RBBB, right bundle branch block; SA block, sino-atrial block; SSS, sick sinus syndrome.

The opinions expressed in this article are not necessarily those of the editors or of the Japanese Circulation Society.

Received May 18, 2014; accepted May 18, 2014; released online June 10, 2014

Department of Pediatric Cardiology, Saitama Medical University International Medical Center, Hidaka, Japan

Mailing address: Naokata Sumitomo, MD, PhD, Department of Pediatric Cardiology, Saitama Medical University International Medical

Center, 1397-1 Yamane, Hidaka 350-1298, Japan. E-mail: sumitomo@ saitama-med.ac.jp

ISSN-1346-9843 doi:10.1253/circj.CJ-14-0564

All rights are reserved to the Japanese Circulation Society. For permissions, please e-mail: cj@j-circ.or.jp 
LQT3 $(63 \%)$ in the Okinawa islands, and all the mutations are E1784K in SCN5A. ${ }^{21}$ From this result, the ancestors of the Okinawa islands may differ from those of the other islands in Japan. As reported, BrS is much more prevalent in the Asian region, ${ }^{24}$ and we need to investigate the prevalence of LQT3 incidence and also E1784K mutations in SCN5A.

In the study by Takahashi et $a,^{21}$ one in 8 of the phenotypes was revealed to have the BrS-type ST elevation while taking mexiletine. Those patients may have an overlapping syndrome of LQT3 and BrS. A closer look at the ST changes in the right precordial leads and 3rd intercostal space right precordial lead recording may be needed when an LQT3 gene anomaly is found, especially an E1784K mutation in SCN5A. Further, great care also must be taken when using sodium-channel blockers and $\beta$-blockers in patients with LQT3.

\section{References}

1. Keating MT. The long QT syndrome: A review of recent molecular genetic and physiologic discoveries. Medicine 1996; 75: 1-5.

2. Bennett PB, Yazawa K, Makita N, George AL Jr. Molecular mechanism for an inherited cardiac arrhythmia. Nature 1995; 376: $683-$ 685 .

3. Chen Q, Kirsch GE, Zhang D, Brugada R, Brugada J, Brugada P, et al. Genetic basis and molecular mechanism for idiopathic ventricular fibrillation. Nature 1998; 392: 293-296.

4. Schott JJ, Alshinawi C, Kyndt F, Probst V, Hoorntje TM, Hulsbeek $\mathrm{M}$, et al. Cardiac conduction defects associate with mutations in SCN5A. Nat Genet 1999; 23: 20-21.

5. Benson DW, Wang DW, Dyment M, Knilans TK, Fish FA, Strieper $\mathrm{MJ}$, et al. Congenital sick sinus syndrome caused by recessive mutations in the cardiac sodium channel gene (SCN5A). J Clin Invest 2003; 112: $1019-1028$

6. Ziyadeh-Isleem A, Clatot J, Duchatelet S, Gandjbakhch E, Denjoy I, Hidden-Lucet F, et al. A truncating SCN5A mutation combined with genetic variability causes sick sinus syndrome and early atrial fibrillation. Heart Rhythm 2014 February 25, doi:10.1016/j.hrthm.2014. 02.021 .

7. Wilde AA, Brugada R. Phenotypical manifestations of mutations in the genes encoding subunits of the cardiac sodium channel. Circ Res 2011; 108: 884-897.

8. Remme CA, Wilde AAM, Bezzina CR. Cardiac sodium channel overlap syndromes: Different faces of SCN5A mutations. Trend Cardiovasc Med 2008; 18: $78-87$

9. Makita N. Phenotypic overlap of cardiac sodium channelopathies: Individual-specific or mutation-specific? Circ J 2009; 73: 810-817.

10. Kato K, Makiyama T, Wu J, Ding WG, Kimura H, Naiki N, et al. Cardiac channelopathies associated with infantile fatal ventricular arrhythmias: From the cradle to the bench. $J$ Cardiovasc Electro- physiol 2014; 25: 66-73.

11. Makita N, Behr E, Shimizu W, Horie M, Sunami A, Crotti L, et al. The E1784K mutation in SCN5A is associated with mixed clinical phenotype of type 3 long QT syndrome. J Clin Invest 2008; 118: 2219-2229.

12. Priori SG, Napolitano C, Schwartz PJ, Bloise R, Crotti L, Ronchetti E. The elusive link between LQT3 and Brugada syndrome: The role of flecainide challenge. Circulation 2000; 102: 945-947.

13. Veldkamp MW, Viswanathan PC, Bezzina C, Baartscheer A, Wilde AA, Balser JR. Two distinct congenital arrhythmias evoked by a multidysfunctional $\mathrm{Na}^{+}$channel. Circ Res 2000; 86: E91-E97, doi:10.1161/01.RES.86.9.e91.

14. Bezzina C, Veldkamp MW, van Den Berg MP, Postma AV, Rook $\mathrm{MB}$, Viersma JW, et al. A single $\mathrm{Na}^{+}$channel mutation causing both long-QT and Brugada syndromes. Circ Res 1999; 85: 1206-1213.

15. Moss AJ, Windle JR, Hall WJ, Zareba W, Robinson JL, McNitt S, et al. Safety and efficacy of flecainide in subjects with long QT-3 syndrome ( $\triangle \mathrm{KPQ}$ mutation): A randomized, double-blind placebocontrolled clinical trial. Ann Noninvasive Electrocardiol 2005; 10: $59-66$.

16. Grant AO, Carboni MP, Neplioueva V, Starmer CF, Memmi M, Napolitano C, et al. Long QT syndrome, Brugada syndrome, and conduction system disease are linked to a single sodium channel mutation. J Clin Invest 2002; 110: 1201-1209.

17. Antzelevitch $\mathrm{C}$. The Brugada syndrome: Ionic basis and arrhythmia mechanisms. J Cardiovasc Electrophysiol 2001; 12: 268-272.

18. Schwartz PJ, Priori SG, Locati EH, Napolitano C, Cantù F, Towbin JA, et al. Long QT syndrome patients with mutations of the SCN5A and HERG genes have differential responses to $\mathrm{Na}^{+}$channel blockade and to increases in heart rate: Implications for gene-specific therapy. Circulation 1995; 92: 3381-3386.

19. Benhorin J, Taub R, Goldmit M, Kerem B, Kass RS, Windman I, et al. Effects of flecainide in patients with new SCN5A mutation: Mutation specific therapy for long-QT syndrome? Circulation 2000; 101: $1698-1706$.

20. Schwartz PJ. The congenital long QT syndromes from genotype to phenotype: Clinical implications. J Intern Med 2006; 259: 39-47.

21. Takahashi K, Shimizu W, Miyake A, Nabeshima T, Nakayashiro M, Ganaha H. High prevalence of the SCN5A E1784K mutation in school children with long QT syndrome living on the Okinawa Islands. Circ J 2014; 78: 1974-1979.

22. Splawski I, Shen J, Timothy KW, Lehmann MH, Priori S, Robinson JL, et al. Spectrum of mutations in long-QT syndrome genes: KVLQT1, HERG, SCN5A, KCNE1, and KCNE2. Circulation 2000; 102: $1178-1185$.

23. Napolitano C, Priori SG, Schwartz PJ, Bloise R, Ronchetti E, Nastoli $\mathrm{J}$, et al. Genetic testing in the long QT syndrome: Development and validation of an efficient approach to genotyping in clinical practice. JAMA 2005; 294: 2975-2980.

24. Murakoshi N, Aonuma K. Epidemiology of arrhythmias and sudden cardiac death in Asia. Circ J 2013; 77: 2419-2431. 